\section{CRUDE CATHEPSIN ACTIVITY AND QUALITY CHARACTERISTIC OF SMOKED CATFISH [Pangasius pangasius (Hamilton, 1882)] PROCESSED BY DIFFERENT SMOKING TEMPERATURE}

Fronthea Swastawatia*, Ahmad Ni'matullah Al Baarrib, Tri Winarni Agustinia, Eko Nurcahya Dewia, Ima Wijayantia, Dwi Yanuar Budi Prasetyoc, Daniel Khand

aLaboratory of Fish Processing Technology, Faculty of Fisheries and Marine Science, Diponegoro University, Jl. Prof Soedarto, SH, Tembalang, Semarang - 50275, Indonesia

bLaboratory of Chemistry and Food Nutrition, Faculty of Animal and Agriculture, Diponegoro University, Semarang - 50275, Indonesia

cMagister Coastal Resource Management, Faculty of Fisheries and Marine Science, Diponegoro University, Jl. Imam Bardjo, SH, Semarang - 50241, Indonesia

ast. Patrick's College, Buchanan House, 30 Holborn, London, EC 1N 2LX, United Kingdom
Article history

Received

6 October 2015

Received in revised form

30 October 2015

Accepted

7 February 2016

*Corresponding author fronthea_thp@yahoo.co.id
Graphical abstract

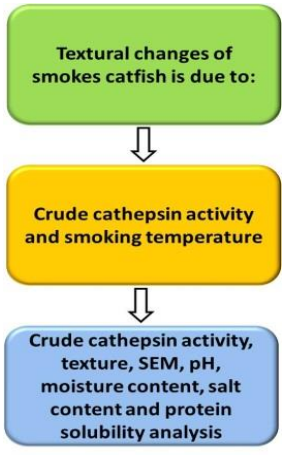

\begin{abstract}
The aim of this research was to investigate the effect of smoking temperature towards crude cathepsin activity and quality characteristic of smoked catfish [Pangasius pangasius (Hamilton, 1882)]. Different smoking temperature had significant effect $(p<0.05)$ on crude cathepsin activity, texture, $\mathrm{pH}$, moisture content, salt content and protein solubility. The significant decreasing $(30.13 \%)$ of crude cathepsin activity was at P3 $\left(80^{\circ} \mathrm{C}\right)$ from P1 $\left(40^{\circ} \mathrm{C}\right.$ to $50^{\circ} \mathrm{C}$ ). Many factors were correlated to the textural changes of smoked catfish such as changes of crude cathepsin activity, reduction of protein solubility and $\mathrm{pH}$ value.

Keywords : Catfish [Pangasius pangasius (Hamilton, 1882)], crude cathepsin activity, quality characteristic, smoking temperature

(C) 2016 Penerbit UTM Press. All rights reserved
\end{abstract}

\subsection{INTRODUCTION}

Catfish [Pangasius pangasius (Hamilton, 1882)] is one of the economic aquaculture fish species contains about $35 \%$ of protein and $10.1 \%$ of lipid with dominant fatty acids profile were lauric acid (13.36 $\%)$, palmitic acid $(26.15 \%)$, oleic acid $(46.07 \%)$ and 
products which is highly perishable, in which after the post mortem the enzymatic decomposition rapidly breaks down the texture of fish components like myofibril and connective tissue. [3], cathepsin enzyme activity could change the structure and firmness. Cathepsin B, L and D were able to decrease a-actinin which is responsible to the fish firmness. A significant correlation was observed between enzymatic activity of cathepsin B and L and muscle degradation of Atlantic salmon [4].

Smoking process could inhibit the enzymatic decomposition. Brinning, pre drying, chemical composition of smoke and heating in smoking process could change the optimum condition of cathepsin to be active. Cathepsinne need a certain condition to optimize their activity, such as temperature, $\mathrm{pH}$, substrate concentration and the presence of metal inhibitor [5]. Nowadays smoking is not only a preservative method but it also gives a specific flavour and taste on smoked fish to increase the consumer acceptability. This role could be obtained using liquid smoke, which is easier to apply and is environmentally safe [6]. The aim of this research was to investigated the effects of smoking temperature to crude cathepsin activity which affect textural changes and quality characteristic of smoked catfish.

\subsection{MATERIAL AND METHOD}

\subsection{Smoking Process}

Smoking method of catfish was performed with some modification [7]. Fillets of catfish were separated into four groups. Each group dipped into $5 \%$ brine and 5 $\%$ liquid smoke for $30 \mathrm{~min}$. Pre-drying in room temperature for about $60 \mathrm{~min}$ and then smoked in the electrical oven at $40^{\circ} \mathrm{C}$ to $50^{\circ} \mathrm{C}(\mathrm{P} 1), 60^{\circ} \mathrm{C}$ to 70 ${ }^{\circ} \mathrm{C}$ (P2) and $80{ }^{\circ} \mathrm{C}$ (P3) for $1 \mathrm{~h}$ each. Then it was chilled in the room temperature and then packed with poliethylene bag before analysis in the laboratory.

\subsection{Crude Cathepsin Activity Analysis}

Proteolytic activity assays was performed with some modification [8]. The sample was prepared by mixing $1 \mathrm{~g}$ of fillet with $1 \mathrm{~mL}$ of aquadest and then it was separated using centrifugation at $2315 \mathrm{rpm}(1 \mathrm{rpm}=$ $1 / 60 \mathrm{~Hz}$ ) for $10 \mathrm{~min}$ at $4{ }^{\circ} \mathrm{C}$. The supernatant was then separated again using centrifugation at $5976 \mathrm{rpm}$ for 10 min at $4{ }^{\circ} \mathrm{C}$. Then the extract was dissolved into 1 $\mathrm{mL} \mathrm{0,1} \mathrm{M} \mathrm{Tris-HCl} \mathrm{buffer} \mathrm{(Aplichem)} \mathrm{pH} \mathrm{7.4,} \mathrm{continued}$ with centrifugation at $9449 \mathrm{rpm}$ for $10 \mathrm{~min}$ at $4{ }^{\circ} \mathrm{C}$. Proteolytic activity was analyzed with hemoglobin 2 $\% \mathrm{pH} 2$ (Oxoid) for the substrate. Substrate solution $(0.5 \mathrm{~mL})$ was incubated with $0.1 \mathrm{~mL}$ enzyme solution at $37{ }^{\circ} \mathrm{C}$ for $10 \mathrm{~min}$. Subsequently, $2 \mathrm{~mL}$ Trichloro Acetid Acid (TCA) $5 \%$ was added and then filltered. The solution gained was filtrated, and then $1 \mathrm{~mL}$ Folin reaction was added. Final solution was read in spectrophotometry on $750 \mathrm{~nm}$, blank and standard solutions (Tirosin) were read in the same wave length.

\subsection{Quality Characteristic Analysis}

\subsubsection{Texture Analysis}

Texture were measured using Texture analyzer TATX2. The probe was pressed into the fillet at a constant speed of $2 \mathrm{~mm} \mathrm{~s}^{-1}$ until it reached $60 \%$ of the sample height. The maximum force obtained during compression (gf) was recorded.

\subsection{2 pH, Moisture Content and Salt Content}

For analysis preparation, $10 \mathrm{~g}$ of samples were homogenized with $90 \mathrm{~mL}$ of distilled water for $1 \mathrm{~min}$. The electrode of $\mathrm{pH}$ meter $(\mathrm{pH}$ meter Hanna Instrument) was inserted into the slurry while being stirred vigorously. After stabilization, the observed value was recorded. Moisture content of samples was measured at $105{ }^{\circ} \mathrm{C}$ according to the gravimetric test. The salt content was determined using Silver Nitrite Method.

\subsubsection{Protein Solubility Analysis}

Protein content in supernatant was divided into two groups of experiment, i.e. set I and set II. Set I was performed with Biuret reaction and set II was using alkaline cooper sulphate reagent. Color was measured using spectrophotometer at $540 \mathrm{~nm}$. Bovine serum albumin was used as the standard solution. All the analysis were run in duplicate.

\subsection{Statistical Analysis}

Randomized Block Design was used in this research and analyzed using ANOVA with significant level of $95 \%$. The computer software for helping this project was SPSS ver 20.

\subsection{RESULTS AND DISCUSSION}

\subsection{Crude Cathepsin Activity}

Crude cathepsin activity on raw catfish was $0.860 \mathrm{U}$. $\mathrm{mL}^{-1}$ and it is comparable with previous experiment [5], which showed that crude chatepsin activity on cat fish after post rigor was $0.278 \mathrm{U} \mathrm{mL}^{-1}(1 \mathrm{U}=1 / 60$ micro katal ). The various results might be influenced by several factors such as sexual maturity level. The highest cathepsin value was reached at sexual maturity season [9]. The statistical analysis showed that smoking temperature gave significant differences for crude cathepsin activity. Based on LSD test the smoking temperature give significant different for crude cathepsin activity. The results showed that there was no significant difference between treatment $\mathrm{PO}$ and $\mathrm{Pl}$ as well as between treatment P2 and P3. Result showed significant 
difference between treatment P1 and P2 (Table 1). Reduction of crude cathepsin activity showed significant at P3 (31.98\%) from P0; $21.16 \%$ from PO to $\mathrm{P} 2$ and $13.72 \%$ from $\mathrm{P} 2$ to $\mathrm{P} 3$.

Table 1 Crude cathepsin activity $\left(\mathrm{U} \mathrm{mL}^{-1}\right)$

\begin{tabular}{lc}
\hline Treatment & Value \\
\hline P0 (Control) & $0.860 \pm 0.06^{\mathrm{a}}$ \\
P1 & $0.880 \pm 0,03^{\mathrm{a}}$ \\
P2 & $0.678 \pm 0,00^{\mathrm{b}}$ \\
P3 & $0.585 \pm 0,02^{\mathrm{b}}$ \\
\hline Note: Average value of duplicate \pm standard deviaton \\
Value following with same small superscript letters were no \\
significantly different $(p>0.05)$.
\end{tabular}

Crude cathepsin activity was decreasing with the increasing of smoking temperature. The highest value of crude cathepsin activity was on smoked catfish at $\mathrm{P} 1\left(40^{\circ} \mathrm{C}\right.$ to $\left.50^{\circ} \mathrm{C}\right)$ then followed by $\mathrm{P} 2\left(60^{\circ} \mathrm{C}\right.$ to 70 $\left.{ }^{\circ} \mathrm{C}\right)$ and $\mathrm{P} 3\left(80^{\circ} \mathrm{C}\right)$ The reduction of crude cathepsin activity may be affected by combination of salt, heat and smoke in catfish smoking process by changing the optimum condition of enzyme to be active (Table 2). It was similar with previous experiment [5] that, the optimum condition to optimalize activity of crude cathepsin were temperature, $\mathrm{pH}$ and metals inhibitor. The optimum temperatures were $40^{\circ} \mathrm{C}$ to $50^{\circ} \mathrm{C}$ and decreasing rapidly with increasing temperature in $60^{\circ} \mathrm{C}$ to $70^{\circ} \mathrm{C}$. The value of optimum $\mathrm{pH}$ for crude cathepsin activity was recorded in the range 6 to 7 , the metals such as $\mathrm{Na}$ could inhibit $85 \%$ relative cathepsin activity. Gross Proteolytic Activity of smoked salmon which smoked at $20^{\circ} \mathrm{C}$ to $30^{\circ} \mathrm{C}$ was $0.535 \mathrm{mg}$ peptides $\mathrm{mg}^{-1}$ [10].

\subsection{Texture}

Based on the data that was shown at Table 2, smoking temperature and protein solubility caused the changes on smoked catfish texture. The increase of smoking temperature affected the decrease in the textural value. Heat treatments lead to denaturation on protein muscle, long heat treatment will form aggregation [11]. The textural change caused by denaturation of protein muscle, then the water soluble protein and the texture tended to semisolid gel structure resulting in the hard texture.

The textural changes of smoked catfish were caused by crude cathepsin activity, even in small amount. Cathepsin activity was correlated to firmness and made textural changes on rainbow trout [12]. This enzyme was responsible for tissue degradation. The range of fibre densities from 85 fibre $\mathrm{mm}^{-2}$ to 140 fibre $\mathrm{mm}^{-2}$ indicates optimum "chewiness" and "firmness" in texture characteristics of smoked salmon. The high fibre densities contributed to a firmer texture in fish muscle, and the variety of fibre densities in fish was affected by sexual maturity [9].

Table 2 Texture (gf), $\mathrm{pH}$, moisture content (wet basis \%), salt content (wet basis \%) and protein solubility (\%) of smoked fillets catfish

\begin{tabular}{lllll}
\hline Parameters & P0 & P1 & P2 & P3 \\
\hline Texture & $5482.43 \pm 93.45^{\mathrm{a}}$ & $4591.37 \pm 27.12^{\mathrm{b}}$ & $4241.93 \pm 56.82^{\mathrm{c}}$ & $3881.29 \pm 26.75^{\mathrm{d}}$ \\
$\mathrm{pH}$ & $7.22 \pm 0.04^{\mathrm{a}}$ & $7.42 \pm 0.02^{\mathrm{b}}$ & $7.72 \pm 0.01^{\mathrm{c}}$ & $8,01 \pm 0.04^{\mathrm{d}}$ \\
Moisture content & $79.66 \pm 0.04^{\mathrm{a}}$ & $77.42 \pm 0.02^{\mathrm{b}}$ & $74.72 \pm 0.01^{\mathrm{c}}$ & $72.04 \pm 0.04^{\mathrm{d}}$ \\
Salt content & $1.43 \pm 0.10^{\mathrm{a}}$ & $2.62 \pm 0.19 \mathrm{~b}$ & $3.88 \pm 0.33^{\mathrm{c}}$ & $5.83 \pm 0.28^{\mathrm{d}}$ \\
Protein Solubility & $14.37 \pm 0.42^{\mathrm{a}}$ & $11.66 \pm 0.12^{\mathrm{b}}$ & $8.32 \pm 0.30^{\mathrm{c}}$ & $5.80 \pm 0.19^{\mathrm{d}}$ \\
\hline
\end{tabular}

Note : Average value of of duplicate measurement \pm standard deviaton.

Value following with same small superscript letters were no significantly different $(p>0.05)$.

\subsection{Scanning Electron Microscope (SEM)}

Textural changes of smoked catfish were measured by Scanning Electron Microscope (SEM). SEM analysis was performed to describe structural changes in texture of smoked catfish. Figure 1 (a) showed that the structure of texture smoked catfish still complex and solid. Figure 1 (b) shows aggregates in the texture of smoked catfish. Bigger aggregates were obtained from catfish which was processed in higher temperature and longer smoking time (Figure 1 (c)). Meanwhile. Figure 1 (d) shows that the texture became hardened and damaged. In the previous research, the aggregate formation increased regularly in meat heated at $60^{\circ} \mathrm{C}$, whereas meat heated at higher temperature $\left(100^{\circ} \mathrm{C}\right.$ and $\left.140^{\circ} \mathrm{C}\right)$ showed dramatic increase up to 5 -fold the initial level. The temperature increase promote exposure the thiol group and interior hydrophobic residues of BSA, enabling the formation of hydrogen bonds and hydrophobic interactions. This reaction and interactions promoted protein aggregation via a non-native and expanded conformational state [11, 13]. 


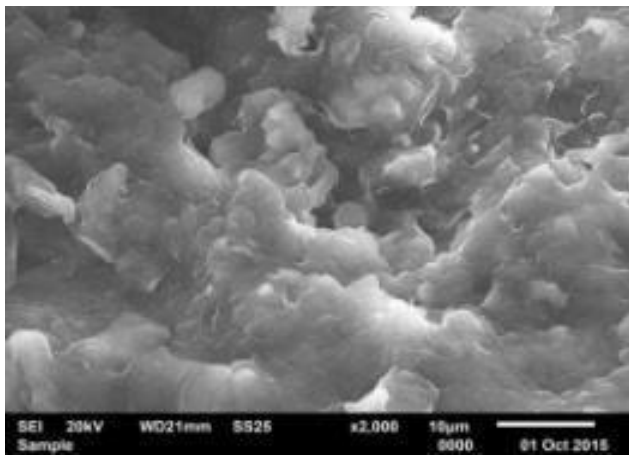

$1(a)$

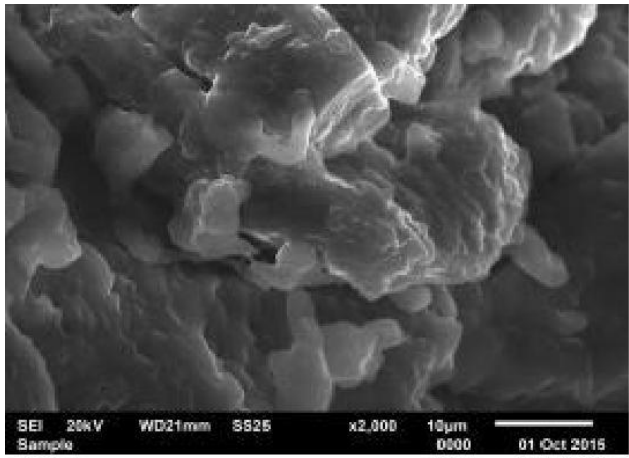

1 (c)

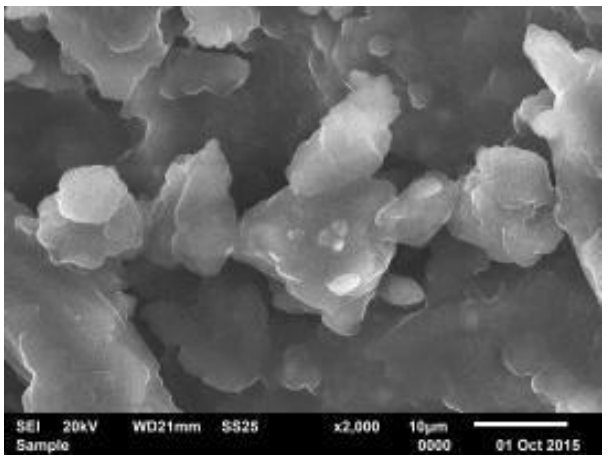

1 (b)

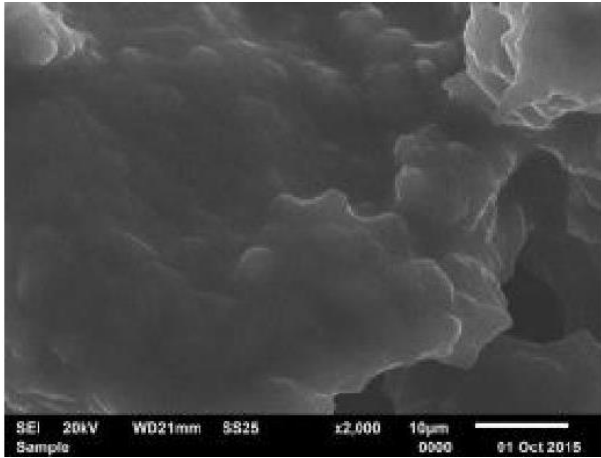

1 (d)

Figure 1 SEM image from smoked catfish with various treatments, i.e. (a) PO, (b) P1, (c) P2 and (d) P3

\section{$3.4 \mathrm{pH}$}

The $\mathrm{pH}$ values of smoked catfish were shown in Table 2. The fresh catfish had $\mathrm{pH}$ values of $7.22 \pm 0.04$, and increased after smoking process. $\mathrm{pH}$ values of smoked fish from this study were 7.42 to 8.01 . According to previous research on smoked stingray, $\mathrm{pH}$ values of smoked stingray using coconut shell and corn cob liquid smoke were 7.30 and 8.20 respectively [6]. The changes on $\mathrm{pH}$ on smoked fish were affected by chemical composition of liquid smoke [14]. The value of $\mathrm{pH}$ is an important role to determine enzyme activity in which $\mathrm{pH}$ affects the ionization condition which needs the bounding between substrate and enzyme. The catalysis reaction depended on interaction between substrate with side chains amino acid which bound the active side of enzyme [15]. When $\mathrm{pH}$ of cathepsin was 6, cathepsin activity was $0.271 \mathrm{U} \mathrm{mL}^{-1}$, but in $\mathrm{pH}$ 7 or above the value of the cathepsin activity decreased $\left(0.167 \mathrm{U} \mathrm{mL}^{-1}\right)$ [5]. This irreversible enzyme was inactive at $\mathrm{pH}$ above 7 but generally highly active at acidic environment [16].

\subsection{Moisture Content}

Moisture content of smoked catfish were $72.04 \%$ to $77.33 \%$, while the moisture content of raw fish was $79.66 \%$. Smoking process caused the reduction in the moisture content of smoked fish and, the combination of salting, pre drying and heating process evaporated the moisture in fish muscle as well. Previous research showed that moisture content of smoked milkfish processed by corn cob liquid smoke was $58.33 \%$ and $63.37 \%$ respectively [7].

\subsection{Salt Content}

The salt content of smoked catfish was $2.62 \%$ to 5.83 $\%$. There was a slight increase in the value of salt content with the increasing of smoking temperature $(p<0.05)$. While smoking temperature increased, moisture evaporated and then the salt penetrated into fish flesh because of the osmosis effect from salt. In other experiment, salt content of smoked salmon were $4.0 \mathrm{~g}$ to $7.2 \mathrm{~g}$ per $100 \mathrm{~g}$ moisture [10]. While salt content of smoked sea bass which were processed by spray with liquid smoke for $30 \mathrm{~min}$ and added with $\mathrm{NaCl}(0.110 \% ; 0.150 \% ; 0.200 \% ; 0.220 \% ; 0.270 \%)$ were $2.05 \% ; 4.46 \% ; 4.83 \% ; 9.40 \%$ and $17.76 \%$ respectively [17].

\subsection{Protein Solubility}

Protein solubility of smoked catfish decreased as a result of increasing smoking temperature, the heating process indicated the changes on protein solubility. The denaturation of protein relates to protein solubility, the tertiary or secondary structure of protein 
was damaged, thus, became primary structure due to heat treatments. In the primary structure, both water and salt soluble protein were released easier than in tertiary or secondary structure. The decreasing solubility of protein occurred because of increased smoking temperature. In the previous research, the protein solubility value of smoked salmon which was smoked at $29.9{ }^{\circ} \mathrm{C}$ were significantly lower than salmon smoked at $21.5^{\circ} \mathrm{C}$ [10]. The changes of protein solubility were due to $\mathrm{pH}$ in which protein solubility increased at extremely acidic and alkaline environment. Previous research showed that at the extreme of $\mathrm{pH}$, solubility increased to almost five times that of the original $(\mathrm{pH}$ 6.3), i.e. $125.73 \pm 0.64 \mathrm{mg} \mathrm{g}^{-1}$ at $\mathrm{pH} 2 ; 58.92 \pm 1.10 \mathrm{mg}$ $\mathrm{g}^{-1}$ at $\mathrm{pH} 4 ; 21.42 \pm 0.5 \mathrm{mg} \mathrm{g}^{-1}$ at $\mathrm{pH} 6 ; 44.76 \pm 0.95$ $\mathrm{mg} \mathrm{g}^{-1}$ at $\mathrm{pH} 8$ and $122.85 \pm 1.2 \mathrm{mg} \mathrm{g}^{-1}$ at $\mathrm{pH} 12$ [18]. Another study showed that minimum protein solubility that called isoelectric point, in raw or cooked samples exhibited at $\mathrm{pH} 5$ to 6 . Protein solubility decreased with increasing $\mathrm{pH}$ to isoelectric point then increased again to high $\mathrm{pH}$ [19].

\subsection{CONCLUSION}

Inceasing smoking temperature could inhibit the crude cathepsin enzyme activity and reduced the texture, moisture content, and protein solubility of smoked catfish. The information from this study could be a reference to produce good quality smoked fish in particular protein nutritive aspect.

\section{Acknowledgement}

The authors would like to acknowledge the financial support provided by Directorate General of Research and Public Services, Ministry of Research, Technology and Higher Education with contract number DIPA023.04.1.673453/2015, November $14^{\text {th }} 2014$ revised on DIPA March $1^{\text {st }} 2015$.

\section{References}

[1] Ministry of Marine Affairs and Fisheries. 2013. Marine and Fisheries in Figures 2013. Jakarta: Centre of Data, Statistic and Information.

[2] Islam, R., D. K. Paul, A. Rahman, T .Parvin, D. Islam, and A. Sattar. 2012. Comparative Characteristic of Lipids and Nutrient Contents of Pangasius pangasius and Pangasius sutchi Available in Bangladesh. Journal Nutrition \& Food Science. 2(2): 130-135.

[3] Ladrat, C., V. Verrez-Bagins, J. Noel, and J. Fleurence. 2003. In Vitro Proteolysis of Myofibrillar and Sarcoplasmic Proteins of White Muscle of Sea Bass (Dicentrachus labrax L.): Effects of Chatepsins B, D and L. Food Chemistry. 81: 517-525.
[4] Bahuaud, D., T. Morkore, O. Langsrud, K. Sinnes, E. Veiseth, and R. Ofstad. 2008. Effects of $-1.5^{\circ} \mathrm{C}$ Super Chilling on Quality of Atlantic Salmon (Salmo salar) Pre-Rigor Fillets: Cathepsin Activity, Muscle Histology, Texture and Liquid Leakage. Food Chemistry. 111: 329-339.

[5] Fikri, M. Z., T. Nurhayati, and E. Salamah. 2014. Ekstraksi dan Karakterisasi Parsial Ekstrak Kasar Enzim Katepsin dari Ikan Patin [Extraction and Partial Characterization of Crude Cathepsin from Catfish]. J. Teknologi dan Industri Pangan. 25 (1): 119-123. [Bahasa Indonesia].

[6] Swastawati, F., E. Susanto, B. Cahyono, and W. A. Trilaksono. 2012. Sensory Evaluation and Chemical Characterictics of Smoked Stingray (Dasyatis blekeery) Processed by Two Different Liquid Smoke. International Journal of Bioscience, Biochemistry and Bioinformatics. 2(3): 212-216.

[7] Swastawati, F., Y. S. Darmanto, L. Sya'rani, K. K. Rahayu, and K. D. A. Taylor. 2014. Quality Characteristic of Smoked Skipjack (Katsuwonus pelamis) Using Different Liquid Smoke. International Journal of Bioscience, Biochemistry and Bioinformatics. 4(2): 94-99.

[8] Dinu, D., I. F. Dumitru, and M. T. Nichifor, 2002. Isolation and Characterization of Two Chatepsin from Muscle of Carasiuss auratus gibelio. Roum Biotechnology. (7): 753758.

[9] Johnston, A. I., R. Alderson, C. Sandham, et al. 2000. Muscle Fibre Density in Relation to the Colour and Texture of Smoked Atlantic Salmon (Salmo salar L.). Aquaculture. $189(3-4): 335-349$.

[10] Lisbeth, H., A. M. B. Rora, I. Steinsland, T. Skara, and T. Rustad, 2004. Proteolytic Activity and Properties of Proteins in Smoked Salmon (Salmo salar) - Effects of Smoking Temperature. Food Chemistry. 85: 377-387.

[11] Kajak-Siemaszko K., L. Aubry, F. Peyrin, et al. 2011. Characterization of Protein Aggregates Following a Heating and Freezing Process. Food Research International. 44: 3160-3166.

[12] Godiksen, H., M. Morzel, G. Hyldig, and F. Jessen, 2008. Contribution of Chatepsin B, L and D to Muscle Protein Profiles Correlated with Texture in Rainbow Trout (Oncorhynchus mykiss). Food Chemistry. 113(4): 889-896.

[13] Su, R., W. Qi, Z. He, Y. Zhang, and F. Jin. 2008. Multileve Structural Nature and Interactions of Bovine Serum Albumin during Heat Induced Aggregation Process. Food Hydrocolloids. 22: 995-1005.

[14] Martines, O. 2007. Textural and Physicochemical Changes in Salmon (Salmo salar) Treated with Commercial Liquid Smoke Flavourings. Food Chemistry. 100: 498-503.

[15] Bender, D. A. 2002. Introduction to Nutrition and Metabolism. Vol. 1. New York: Taylor \& Francis Inc.

[16] Ahmed, Z., O. Donkor, W. A. Street, and T. Vasiljevic. 2015. Calpains - and Cathepsins - Induced Myofibrillar Changes in Post-Mortem Fish: Impact on Structural Softening and Release of Bioactive Peptides. Trends in Food Science \& Technology. 45: 130-146.

[17] Fuentes, A., I. Fernandez-Segvovia, J. A.Serr, and J. M. Barat, 2010. Development of a Smoked Sea Bass Product with Partial Sodium Replacement. LWT - Food Science and Technology. 43: 1426-1433.

[18] Mohan, M., D. Ramachandran, T.V. Sankar, and R. Anandan, 2007. Influence of $\mathrm{pH}$ on the Solubility and Conformational Characteristic of Muscle Proteins from Mullet (Mugil cephalus). Process Biochemistry. (42): 10561062

[19] Ghelichpour, M. and B. Shabanpour. 2011. The Investigation of Proximate Composition and Protein Solubility in Processed Mullet Fillets. International Food Research Journal. 18(4): 1343-1347. 